\title{
. \\ ESBL-Producing Moellerella wisconsensis-The Contribution of Wild Birds in the Dissemination of a Zoonotic Pathogen
}

\author{
Zoi Athanasakopoulou ${ }^{1}$, Marina Sofia ${ }^{1}$, Alexios Giannakopoulos ${ }^{1}$, Konstantinos Papageorgiou ${ }^{2,3}$, \\ Dimitris C. Chatzopoulos ${ }^{2}\left(\mathbb{D}\right.$, Vassiliki Spyrou ${ }^{4}$, Evanthia Petridou $\left.{ }^{3}{ }^{(}\right)$, Efthymia Petinaki ${ }^{5}$ \\ and Charalambos Billinis $1,2, * \mathbb{D}$
}

check for updates

Citation: Athanasakopoulou, Z.; Sofia, M.; Giannakopoulos, A.; Papageorgiou, K.; Chatzopoulos, D.C.; Spyrou, V.; Petridou, E.;

Petinaki, E.; Billinis, C.

ESBL-Producing Moellerella wisconsensis-The Contribution of Wild Birds in the Dissemination of Zoonotic Pathogen. Animals 2022, 12, 340. https://doi.org/10.3390/ ani12030340

Academic Editors: Paolo Tizzani, Valentina Lamorgia and Angela Fanelli

Received: 6 January 2022

Accepted: 28 January 2022

Published: 30 January 2022

Publisher's Note: MDPI stays neutral with regard to jurisdictional claims in published maps and institutional affiliations.

Copyright: (C) 2022 by the authors. Licensee MDPI, Basel, Switzerland. This article is an open access article distributed under the terms and conditions of the Creative Commons Attribution (CC BY) license (https:// creativecommons.org/licenses/by/ $4.0 /)$.
1 Faculty of Veterinary Science, University of Thessaly, 43100 Karditsa, Greece; zathanas@uth.gr (Z.A.); msofia@uth.gr (M.S.); algiannak@uth.gr (A.G.)

2 Faculty of Public and One Health, University of Thessaly, 43100 Karditsa, Greece; pgkostas@yahoo.gr (K.P.); dchatzopoulos@uth.gr (D.C.C.)

3 Faculty of Veterinary Medicine, Aristotle University of Thessaloniki, 54124 Thessaloniki, Greece; epetri@vet.auth.gr

4 Faculty of Animal Science, University of Thessaly, 41110 Larissa, Greece; vasilikispyrou@uth.gr

5 Faculty of Medicine, University of Thessaly, 41500 Larissa, Greece; petinaki@uth.gr

* Correspondence: billinis@uth.gr

Simple Summary: Moellerella wisconsensis is a potentially zoonotic pathogen that has sporadically been isolated from animals and humans. In the present study, we describe the occurrence of the organism among 445 wild bird and 2000 human fecal samples, in the context of an investigation regarding antimicrobial resistant bacteria in Greece. According to our results, $0.9 \%(n=4)$ of the examined wild birds were found to be colonized by $M$. wisconsensis, while no human was a carrier of the bacterium. Out of the total number of four M. wisconsensis strains that we detected, three presented resistance to $3 \mathrm{rd}$ generation cephalosporins, were phenotypically confirmed to produce extended spectrum beta lactamases (ESBLs) and harbored bla $\mathrm{CTX-M-1}$. Resistance to tetracyclines, aminoglycosides and trimethoprim/sulfamethoxazole was additionally detected in three, two and one of the ESBL isolates, respectively. This is the first report that presents the dissemination of $M$. wisconsensis in wild bird from Greece and describes CTX-M-1 production in multidrug resistant wild birds' isolates of this bacterial species.

Abstract: Moellerella wisconsensis is an Enterobacteriaceae with unclarified dispersion and pathogenicity. During an ongoing investigation about antimicrobial resistance in Greece, the occurrence of M. wisconsensis was evaluated among wild birds and humans. A total of 445 wild bird and 2000 human fecal samples were collected and screened for the presence of the organism. Subsequently, all $M$. wisconsensis strains were phenotypically and molecularly characterized regarding their antimicrobial resistance characteristics. Four M. wisconsensis were isolated from a common pheasant (Phasianus colchicus), two Eurasian magpies (Pica pica) and a great white-fronted goose (Anser albifrons). Among these four strains, the three latter presented resistance to 3rd generation cephalosporins, were phenotypically confirmed to produce ESBLs and were found to harbor bla $a_{\mathrm{CTX}-\mathrm{M}-1}$. The three ESBL isolates additionally exhibited resistance to tetracyclines, while resistance to aminoglycosides was detected in two of them and to trimethoprim/sulfamethoxazole in one. No Moellerella wisconsensis strains were retrieved from the human samples tested. This is the first report that provides evidence of $M$. wisconsensis dissemination among wild birds in Greece, describing CTX-M-1 production in multidrug resistant wild birds' isolates of this bacterial species.

Keywords: Moellerella wisconsensis; ESBL; multidrug resistance; Enterobacteriaceae; wild birds; Greece; CTX-M-1 


\section{Introduction}

The genus Moellerella includes a monophyletic species, Moellerella wisconsensis (M. wisconsensis), which was named after Wisconsin USA, where the majority of the earliest detected strains originated from [1]. M. wisconsensis, previously designated as Enteric Group 46, is a gram negative, nonmotile, facultative anaerobic and fermentative bacillus. It is a member of the Enterobacteriaceae family, presents the general characteristics of the family, and is taxonomically mostly related to Providencia spp. M. wisconsensis additionally exhibits intrinsic resistance to colistin and polymyxin $\mathrm{B}$, which is considered to be a key feature for its identification [1,2].

Despite that almost forty years have passed since the first detection of $M$. wisconsensis in 1984, its exact distribution and potential pathogenicity remain widely unknown. The bacterium has been isolated from human clinical specimens and has been implicated in cases of gastroenteritis, diarrhea, cholecystitis, bacteremia, peritonitis and urinary tract infections [1-7]. Additionally, it has been retrieved from both domestic and wild animals, as well as from insects and parasites, and has been identified as the causative agent of animal disease [8-12]. However, its role in the etiology of clinical conditions has not been fully elucidated, given the infrequent human and animal colonization. Notably, the scarcity of reported infections caused by $M$. wisconsensis has been partly ascribed to its misidentification as Escherichia coli (E. coli) or Klebsiella pneumoniae subsp. ozaenae [13]. Subsequently, $M$. wisconsensis can be regarded as a rare, though potentially underestimated, opportunistic, zoonotic pathogen with virulence that remains to be clarified.

According to the Centers for Disease Control and Prevention, Enterobacteriaceae that produce extended spectrum beta lactamases (ESBL) are classified as a serious threat for healthcare settings and the community [14]. ESBL carriage in wild birds is perceived to be a result of a spill-over phenomenon through environmental pollution with human or domestic animal strains. Wild birds can, thus, either become colonized by already resistant bacteria via their contact with human waste, sewage, and livestock manure or acquire ESBL genes horizontally from resistant isolates that occur in their environment [15]. ESBL-producing Enterobacteriaceae (ESBL-PE) seem to be particularly disseminated among aquatic associated, omnivorous and synanthropic species, while migratory wild birds are of the most concern for their further dispersal [16-18].

The aim of the present study was to describe the occurrence of $M$. wisconsensis, a rather rare Enterobacteriaceae, among fecal samples of wild birds and humans in Greece and to present its antimicrobial resistance profile.

\section{Materials and Methods}

\subsection{Sample Collection}

During an ongoing investigation regarding antimicrobial resistant bacteria in Greece, non-duplicated fecal samples were collected from 445 wild birds as well as from 2000 patients of the University Hospital of Larissa, between January 2019 and June 2021.

Wild birds were captured using Larsen and Australian type traps, as well as modified bird catching nets, sampled directly from the cloaca and immediately released, according to the prerequisites of the Greek Legislation. Alternatively, samples were collected after identifying the wild bird species, scaring off the bird, and then sampling the freshly dropped feces. Specimens were obtained using sterile cotton swabs and were placed in Amies transport medium (Transwab ${ }^{\circledR}$ Amies, Leicester, UK). Transportation was performed under refrigeration and the samples arrived in the laboratory within $48 \mathrm{~h}$ of their initial collection. The sampling sites of wild birds were located in a variety of habitats, including urban and suburban areas, wetlands, pastures, scrubs/meadows, forests, agroforestry formations and agricultural areas. The exact sampling position of each wild bird was recorded using handheld Global Positioning System (GPS) units (GPSMAP 62s, Garmin Ltd., Southampton, UK).

Human samples originated from the University Hospital of Larissa, a tertiary care 600-bed hospital in Thessaly region (Central Greece), which serves a population of ap- 
proximately 1,000,000 inhabitants. All patients' fecal swabs were retrieved for routine cultures at the time of admission to the hospital and prior to the administration of any antibiotic therapy.

\subsection{Isolation, Identification and Antimicrobial Resistance Phenotype of Moellerella wisconsensis}

Swabs were directly streaked onto both MacConkey agar and ESBL selective agar $\left(\mathrm{CHROMID}^{\circledR}\right.$, BioMérieux, Marcy l'Etoile, France). One colony per plate was selected and further processed. Identification and antimicrobial susceptibility testing of the obtained strains were performed using the Vitek-2 system (BioMérieux, Marcy l'Etoile, France) and the GN ID and AST-GN96 cards, respectively, as previously described [19]. Isolates were characterized as multidrug resistant (MDR) when they presented diminished susceptibility to at least one agent of more than three classes of antibiotics.

Bacterial DNA of all the isolates that were identified as M. wisconsensis was extracted from overnight cultures using the PureLink ${ }^{\mathrm{TM}}$ Genomic DNA Mini Kit (Invitrogen, Darmstadt, Germany), according to the manufacturer's instructions for Gram-negative bacteria. Subsequently, the identity of the isolates was verified by amplification of a $760 \mathrm{bp}$ fragment of the 16S rDNA via PCR [20] (Table 1 and sequencing of the amplicons (3730xl DNA Analyzer, Applied Biosystems, Foster City, CA, USA).

Table 1. Primer sequences, amplicon size and optimal annealing temperature of each simplex PCR performed in the study.

\begin{tabular}{|c|c|c|c|}
\hline Target & Primer Sequence $\left(5^{\prime}-3^{\prime}\right)$ & Amplicon Size (bp) & $\begin{array}{c}\text { Annealing } \\
\text { Temperature }\left({ }^{\circ} \mathrm{C}\right)\end{array}$ \\
\hline $\begin{array}{l}\text { Moellerella wisconsensis } \\
\text { 16S rDNA }\end{array}$ & $\begin{array}{l}\text { F: CTC GTT GCG GGA CTT AAC } \\
\text { R: ACT CCT ACG GGA GGC AGC A }\end{array}$ & 760 & 60 \\
\hline$b l a_{\mathrm{CTX}-\mathrm{M}}$ & $\begin{array}{l}\text { F: ATG TGC AGY ACC AGT AAR GTK ATG GC } \\
\text { R: TGG GTR AAR TAR GTS ACC AGA AYC AGC GG }\end{array}$ & 593 & 60 \\
\hline$b^{b l a_{\mathrm{SHV}}}$ & $\begin{array}{l}\text { F: CTT TAT CGG CCC TCA CTC AA } \\
\text { R: AGG TGC TCA TCA TGG GAA AG }\end{array}$ & 327 & 60 \\
\hline$b l a_{\mathrm{TEM}}$ & $\begin{array}{c}\text { F: CGC CGC ATA CAC TAT TCT CAG AAT GA } \\
\text { R: ACG CTC ACC GGC TCC AGA TTT AT }\end{array}$ & 445 & 62 \\
\hline
\end{tabular}

\subsection{Phylogenetic Analysis}

The 16S rDNA sequences of the strains obtained in the present study and of all the $M$. wisconsensis sequences available in GenBank $(n=20)$ were aligned by ClustalW. The phylogenetic tree was constructed with the Neighbor-Joining method [21] and the evolutionary distances were computed using the Kimura 2-parameter [22]. A bootstrap resampling analysis for 1000 replicates was performed to estimate the confidence of tree topologies [23]. Analyses were conducted in MEGA 11 [24].

\subsection{Phenotypic Evaluation and Molecular Confirmation of ESBL Production}

According to the results of susceptibility testing, $M$. wisconsensis isolates that presented resistance to 3rd generation cephalosporins (cefoperazone, ceftiofur) were phenotypically screened for ESBL production by the double-disk synergy test (DDST) [25]. Isolates that presented a positive DDST were further subjected to molecular confirmation. Simplex PCRs were performed for the amplification of genes encoding the most common types of ESBLs, namely CTX-M, TEM and SHV, using the primers described by Dandachi I. et al. [26] (Table 1). In all the assays, sterile distilled water served as negative control, while confirmed ESBL-producing Enterobacteriaceae from our strains' collection were used as positive control. Post-amplification products were visualized on $2 \%$ agarose gel electrophoresis. The PCR products were purified and analyzed by sequencing (3730xl DNA Analyzer, Applied Biosystems). 


\section{Results}

A total number of four $(4 / 445 ; 0.9 \%)$ wild birds were found to be colonized with M. wisconsensis. The strains were identified according to their biochemical characteristics (Appendix A, Table A1). In particular, M. wisconsensis was isolated from the fecal samples of a common pheasant (Phasianus colchicus) originating from Atalanti island, two Eurasian magpies (Pica pica) from Lake Karla and a great white-fronted goose (Anser albifrons) from Lake Pamvotis. M. wisconsensis was not detected in any of the tested human samples.

Sequence analysis of the $16 \mathrm{~S}$ rDNA confirmed the presence of $M$. wisconsensis in all four wild birds' samples. The four Greek isolates were aligned on a region of 675 nucleotides with 20 isolates from humans, animals and insects that had previously been deposited in GenBank and were found to present over $99.9 \%$ similarity with them. The evolutionary relationships between the 24 sequences were described by a Neighbor-Joining tree (Figure 1).

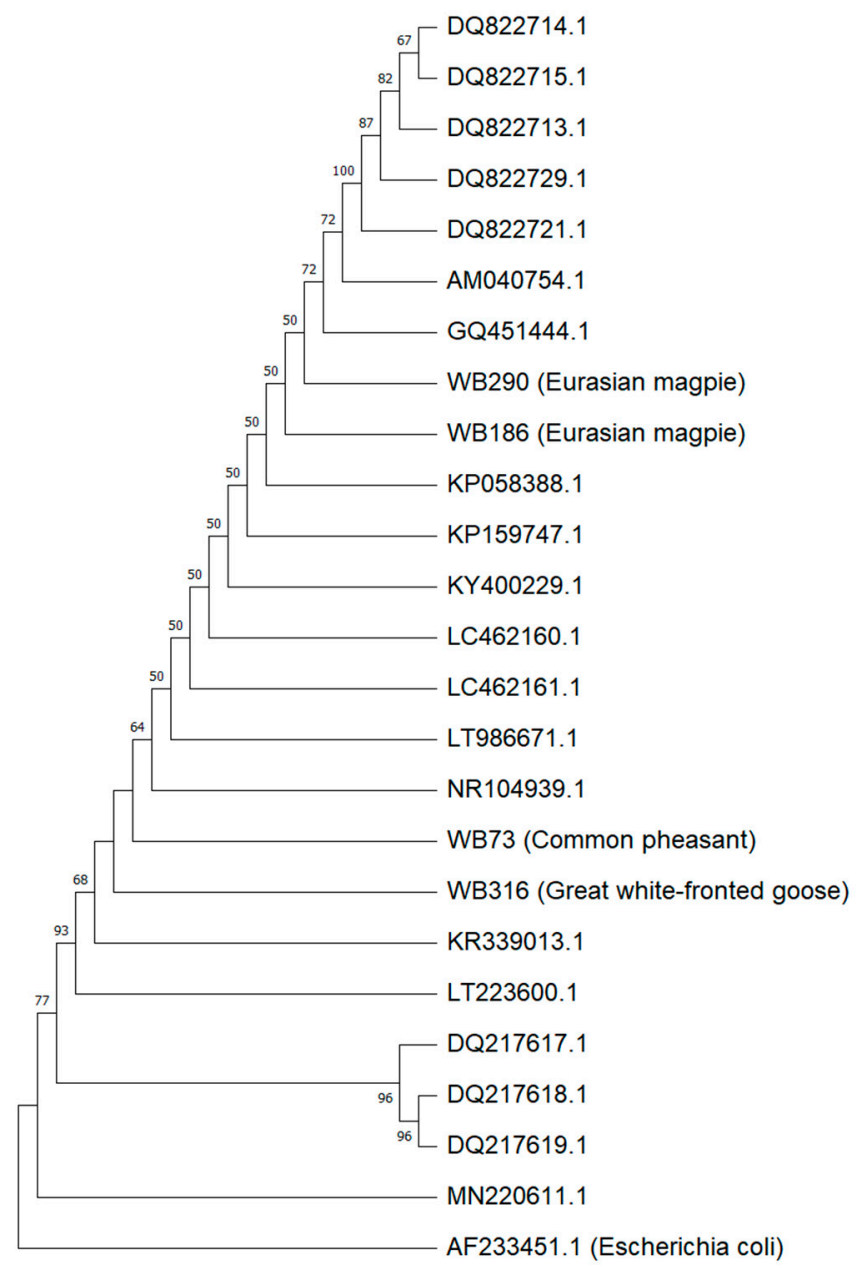

Figure 1. Phylogenetic tree constructed with Neighbor-Joining method by using the four 16S rDNA sequences of Greek M. wisconsensis isolates (WB73, WB186, WB290, WB316; in red boxes) and 20 M. wisconsensis sequences retrieved from the GenBank database. E. coli strain AF233451.1 was used as the outgroup. Bootstrap values (expressed as percentages of 1000 replications) are shown at the branch points; only values over $50 \%$ are indicated.

All the isolates presented resistance to polymixin B. The strain isolated from the common pheasant was obtained from MacConkey agar and was additionally resistant to cefalexin. The remaining three strains were obtained from ESBL selective agar and presented the ESBL phenotype, being resistant to penicillins (ampicillin) and 1st to 4th generation cephalosporins. These three ESBL strains were also resistant to tetracyclines, while two of them, one from a magpie and the one from goose, exhibited reduced susceptibility to 
aminoglycosides. The aminoglycosides resistant magpie strain was further resistant to trimethoprim/sulfamethoxazole.

Molecular screening for ESBL encoding genes in the three phenotypic ESBL producers revealed that they all carried $b l a_{\mathrm{CTX}-\mathrm{M}-1}$, while $b l a_{\mathrm{TEM}}$ and $b l a_{\mathrm{SHV}}$ were not detected in any isolate.

The characteristics of the four M. wisconsensis isolates are summarized in Table 2.

Table 2. Origin, antimicrobial resistance profile and ESBL genes of the M. wisconsensis isolates.

\begin{tabular}{|c|c|c|c|c|c|}
\hline Strain ID & Wild Bird Species & Region & Regional Unit & $\begin{array}{c}\text { Antimicrobial } \\
\text { Resistance Phenotype }\end{array}$ & ESBL Genotype \\
\hline WB73 & $\begin{array}{l}\text { Common pheasant } \\
\text { (Phasianus colchicus) }\end{array}$ & Atalanti island & Fthiotida & CEX, PMB & - \\
\hline WB186 & $\begin{array}{l}\text { Eurasian magpie } \\
\quad(\text { Pica pica })\end{array}$ & Lake Karla & Magnesia & $\begin{array}{l}\text { AMP, CEX, CF, CEP, } \\
\text { CEF, CEQ, TET, PMB }\end{array}$ & $b l a_{\mathrm{CTX}-\mathrm{M}-1}$ \\
\hline WB290 & $\begin{array}{l}\text { Eurasian magpie } \\
\quad(\text { Pica pica })\end{array}$ & Lake Karla & Magnesia & $\begin{array}{l}\text { AMP, CEX, CF, CEP, } \\
\text { CEF, CEQ, GEN, TET, } \\
\text { PMB, SXT }\end{array}$ & $b l a_{\mathrm{CTX}-\mathrm{M}-1}$ \\
\hline WB316 & $\begin{array}{l}\text { Great white-fronted } \\
\text { goose (Anser albifrons) }\end{array}$ & Lake Pamvotis & Ioannina & $\begin{array}{l}\text { AMP, CEX, CF, CEP, } \\
\text { CEF, CEQ, GEN, NEO } \\
\text { * , TET, PMB }\end{array}$ & $b l a_{\mathrm{CTX}-\mathrm{M}-1}$ \\
\hline
\end{tabular}

\section{Discussion}

In the present study, we detected carriage of $M$. wisconsensis by $0.9 \%$ of the sampled wild birds and specifically by a common pheasant, two magpies and a great white-fronted goose and we describe the presence of three MDR ESBL-producing $M$. wisconsensis for the first time in Greece. Notably, the organism was not identified in the examined human samples, confirming that $M$. wisconsensis is a rare clinical isolate [2].

Even though $M$. wisconsensis is probably part of the normal gastrointestinal microbiota, its natural habitat is speculated to be associated with the environment and particularly with water [1]. Our results support this claim, since $M$. wisconsensis was detected in four wild birds' samples that lived in proximity to three different aquatic environments (Atalanti island, lake Karla, lake Pamvotis) but not in any samples collected from wild birds inhabiting other types of environments.

The isolation of $M$. wisconsensis from wild animals has sparsely been reported in previous studies. In the USA, Bangert $R$. and colleagues have identified fecal carriage of the bacterium by $9 \%$ of the examined captive raptors (Falconiformes and Strigiformes), which were on a diet primarily consisting of commercially prepared chicken [27]. Given the fact that these wild birds were under captivity, it cannot be inferred whether the presence of the bacterium represented a natural colonization or was a result of their interaction with humans. In the same country, $M$. wisconsensis has also been retrieved from the oral secretions of a wild raccoon, which was suggested to be a zoonotic reservoir of the organism [10], while, in Italy, it has been isolated from fecal samples of foxes, mustelids and a wolf [28].

Three of the isolated M. wisconsensis, from the two magpies and the goose, presented diminished susceptibility to at least one agent of more than three antimicrobial categories and were subsequently characterized as multidrug resistant [29]. The fact that these strains harbored an ESBL gene could indicate a human or livestock to wildlife transmission of either the strain itself or of its resistance determinants. However, ESBL-producing M. wisconsensis was neither detected in the human samples that we examined nor has, to date, been reported from Greece in human or other animal samples. Thus, the second hypothesis seems more plausible. Nevertheless, further studies are required to fully elucidate either of the speculations. bla $a_{\mathrm{CTX}-\mathrm{M}-1}$ was the only ESBL gene that we detected, a finding that 
is in agreement with data on the current molecular epidemiology of ESBL-producing Enterobacteriaceae among both domestic and wild animals worldwide [30-32]. A sole former study has described ESBL carriage in a single $M$. wisconsensis isolate that was retrieved from flies trapped in the surrounding area of a hospital in Ethiopia [33]. In that study, though, $M$. wisconsensis carried the $b l_{\text {TEM }}$ ESBL gene (personal communication with Dr. Tufa, T.B.).

Stock $I$. et al. have previously detailed the natural antibiotic susceptibility of M. wisconsensis. According to their findings, the species presents natural sensitivity to aminoglycosides, fluoroquinolones, folate-pathway inhibitors (trimethoprim/sulfamethoxazole) and tetracyclines [13]. The resistance profile of the three MDR isolates in our study is therefore, presumably, a result of acquired antimicrobial resistance mechanisms. Genes encoding ESBLs are most commonly located on transferable plasmids, rather than the bacterial genome, which frequently also carry resistance determinants for various other antimicrobial classes, including the aforementioned ones [34]. This fact, along with the ability of Enterobacteriaceae to acquire multiple plasmids, as well as to mutate against antimicrobials could explain the reported multidrug resistance in our strains [35].

Carriage of MDR, ESBL-producing Enterobacteriaceae from magpies is probably associated with the birds synanthropic, omnivorous and scavenging behavior, as has previously been described for E. coli strains isolated from the species [19,36]. Adult magpies are sedentary, while the dispersion of juveniles is limited and does not extend beyond $30-40 \mathrm{~km}$ from the place of birth. Lake Karla, however, where the two ESBL M. wisconsensis from magpies were detected, is a site of great importance for migratory and overwintering waterbirds and foraging raptors in Greece. Subsequently, these birds could obtain the strains and further contribute to their environmental dissemination across long distances during migration. Correspondingly, the great white-fronted goose, that was also found to be colonized by a MDR ESBL-producing $M$. wisconsensis, is a migratory species that conducts long and short distance migration with a potential to diffuse both $M$. wisconsensis and $b a_{\mathrm{CTX}-\mathrm{M}-1}$. This bird most probably acquired the resistant strain or the respective resistance determinants from its habitat, since lake Pamvotis is known to be impaired by pollutants from sewage [37].

\section{Conclusions}

In conclusion, this study revealed wild birds' colonization with $M$. wisconsensis in Greece. Three out of the four isolates presented a multidrug resistant, ESBL-producing phenotype and harbored $b l a_{\mathrm{CTX}-\mathrm{M}-1}$. Our findings underline the potential role of wild birds in both the spread of M. wisconsensis and the dissemination of bla $a_{\mathrm{CTX}-\mathrm{M}-1}$.

Author Contributions: Conceptualization, Z.A.; D.C.C.; V.S.; E.P. (Efthymia Petinaki) and C.B.; methodology, Z.A.; M.S.; K.P.; V.S.; E.P. (Evanthia Petridou); E.P. (Efthymia Petinaki) and C.B. software, Z.A.; M.S. and C.B.; validation, Z.A.; M.S.; V.S.; E.P. (Efthymia Petinaki) and C.B.; formal analysis, Z.A.; investigation, Z.A.; M.S.; K.P.; D.C.C. and E.P. (Evanthia Petridou); resources, A.G.; data curation, Z.A.; writing—original draft preparation, Z.A.; writing—review and editing, Z.A.; M.S.; V.S.; E.P. (Evanthia Petridou); E.P. (Efthymia Petinaki) and C.B.; visualization, Z.A. and M.S.; supervision, V.S.; E.P. (Efthymia Petinaki) and C.B.; project administration, V.S.; E.P. (Efthymia Petinaki) and C.B.; funding acquisition, M.S., A.G., D.C.C., V.S., E.P. (Efthymia Petinaki) and C.B. All authors have read and agreed to the published version of the manuscript.

Funding: This work has been co-funded by the European Union and the General Secretariat for Research and Innovation, Ministry of Development \& Investments, under the project «Novel technologies for surveillance and characterization of Extended-spectrum $\beta$-lactamase and Carbapenemase producing Enterobacteriaceae, in humans and animals (CARBATECH)» T2DGE-0944, of the Bilateral S\&T Cooperation Program Greece-Germany 2017. This support is gratefully acknowledged.

Institutional Review Board Statement: All wild bird samples were obtained by noninvasive cloacal swabs and no research on animals, as defined in the EU Ethics for Researchers document (European Commission, 2013, Ethics for Researchers-Facilitating Research Excellence in FP7, Luxembourg: Office for Official Publications of the European Communities, ISBN 978-92-79-28854-8), was carried 
out for this study. An official permission for capturing and sampling migratory and resident wild birds was provided by the Hellenic Ministry of Environment and Energy (181997/1000/10-5-2019). Capturing, handling and sampling wild birds complied with European and national legislation.

Informed Consent Statement: All humans included in the study gave their informed consent before participation. The study was conducted in accordance with the Declaration of Helsinki, and the protocol was approved by the Scientific Board of the General University Hospital of Larissa (37000/02-08-2018). All samples were obtained by noninvasive rectal swabs that were collected during routine practice.

Data Availability Statement: Most data for this study are presented within the manuscript. The remaining data are available on request from the corresponding author. The data are not publicly available as they are part of the PhD thesis of the first author, which has not yet been examined, approved and uploaded in the official depository of PhD theses from Greek Universities.

Conflicts of Interest: The authors declare no conflict of interest.

\section{Appendix A}

Table A1. Biochemical characteristics of the four Moellerella wisconsensis strains detected in the study.

\begin{tabular}{|c|c|c|c|c|}
\hline Biochemical Reaction & WB73 & WB186 & WB290 & WB316 \\
\hline Probability of correct identification & $99 \%$ & $99 \%$ & $99 \%$ & $99 \%$ \\
\hline Ala-Phe-Pro-Arylamidase & - & - & - & - \\
\hline Adonitol & + & + & + & + \\
\hline L-Pyrrolydonyl-Arylamidase & - & - & - & - \\
\hline L-Arabitol & - & - & - & - \\
\hline D-Cellobiose & - & - & - & - \\
\hline Beta-Galactosidase & + & + & + & + \\
\hline H2S Production & - & - & - & - \\
\hline Beta-N-Acetyl-Glucosaminidase & - & - & - & - \\
\hline Glutamyl Arylamidase pNA & - & - & - & - \\
\hline D-Glucose & + & + & + & + \\
\hline Gamma-Glutamyl-Transferase & - & - & - & - \\
\hline Fermentation/Glucose & + & + & + & + \\
\hline Beta-Glucosidase & - & + & $(-)$ & + \\
\hline D-Maltose & - & - & - & - \\
\hline D-Mannitol & - & - & - & - \\
\hline D-Mannose & + & + & + & + \\
\hline Beta - Xylosidase & - & - & - & - \\
\hline BETA-Alanine arylamidase pNA & - & - & - & - \\
\hline L-Proline Arylamidase & - & - & - & - \\
\hline Lipase & - & - & - & - \\
\hline Palatinose & - & - & - & - \\
\hline Tyrosine Arylamidase & + & + & + & + \\
\hline Urease & - & - & - & - \\
\hline D-Sorbitol & - & - & - & - \\
\hline Saccharose/Sucrose & + & + & + & + \\
\hline D-Tagatose & - & - & - & - \\
\hline D-Trehalose & - & - & - & - \\
\hline Citrate (Sodium) & + & + & + & + \\
\hline Malonate & - & - & - & - \\
\hline 5-Keto-D-Gluconate & - & - & - & - \\
\hline L-Lactate Alkalinisation & - & - & - & - \\
\hline Alpha-Glucosidase & - & - & - & - \\
\hline Succinate alkalinisation & + & + & + & + \\
\hline Beta-N-Acetyl-Galactosaminidase & - & - & - & - \\
\hline Alpha-Galactosidase & $(+)$ & + & + & + \\
\hline Phosphatase & + & $(-)$ & $(+)$ & + \\
\hline Glycine Arylamidase & - & - & - & - \\
\hline Ornithine Decarboxylase & - & - & - & - \\
\hline
\end{tabular}


Table A1. Cont.

\begin{tabular}{ccccc}
\hline Biochemical Reaction & WB73 & WB186 & WB290 & WB316 \\
\hline Lysine Decarboxylase & - & - & - & - \\
L-Histidine assimilation & - & - & - & - \\
Coumarate & + & + & - & - \\
Beta-Glucoronidase & - & + & - & - \\
O/129 Resistance (comp.vibrio.) & - & - & - & - \\
Glu-Gly-Arg-Arylamidase & - & - & - & - \\
L-Malate assimilation & - & - & -
\end{tabular}

" + "- positive reaction, " - " - negative reaction, reactions that appear in parentheses are indicative of weak reactions that are too close to the test threshold.

\section{References}

1. Hickman-Brenner, F.W.; Huntley-Carter, G.P.; Saitoh, Y.; Steigerwalt, A.G.; Farmer, J.J.; Brenner, D.J. Moellerella wisconsensis, a New Genus and Species of Enterobacteriaceae Found in Human Stool Specimens. J. Clin. Microbiol. 1984, 19, 460-463. [CrossRef] [PubMed]

2. Cardentey-Reyes, A.; Jacobs, F.; Struelens, M.J.; Rodriguez-Villalobos, H. First Case of Bacteremia Caused by Moellerella Wisconsensis: Case Report and a Review of the Literature. Infection 2009, 37, 544. [CrossRef] [PubMed]

3. Wittke, J.-W.; Aleksić, S.; Wuthe, H.-H. Isolation of Moellerella wisconsensis from an Infected Human Gallbladder. Eur. J. Clin. Microbiol. 1985, 4, 351-352. [CrossRef] [PubMed]

4. Aller, A.I.; Castro, C.; Medina, M.J.; González, M.T.; Sevilla, P.; Morilla, M.D.; Corzo, J.E.; Martín-Mazuelos, E. Isolation of Moellerella wisconsensis from Blood Culture from a Patient with Acute Cholecystitis. Clin. Microbiol. Infect. 2009, 15, 1193-1194. [CrossRef] [PubMed]

5. Leroy, A.-G.; Malandain, D.; Duchalais, É.; Meurette, G.; Corvec, S. Accurate MALDI-TOF Mass Spectrometry Identification of a Colistin-Resistant Moellerella wisconsensis Strain. Med. Mal. Infect. 2016, 46, 233-235. [CrossRef] [PubMed]

6. Wallet, F.; Fruchart, A.; Bouvet, P.J.M.; Courcol, R.J. Isolation of Moellerella wisconsensis from Bronchial Aspirate. Eur. J. Clin. Microbiol. Infect. Dis. 1994, 13, 182-183. [CrossRef] [PubMed]

7. Ballesteros-Monrreal, M.G.; Arenas-Hernández, M.M.P.; Barrios-Villa, E.; Juarez, J.; Álvarez-Ainza, M.L.; Taboada, P.; De la Rosa-López, R.; Bolado-Martínez, E.; Valencia, D. Bacterial Morphotypes as Important Trait for Uropathogenic E. coli Diagnostic; A Virulence-Phenotype-Phylogeny Study. Microorganisms 2021, 9, 2381. [CrossRef]

8. Zambarbieri, J.; Grilli, G.; Vitiello, T.; Scarpa, P. Urinary Tract Infection by Atypical Uropathogens in Dogs. Vet. Ital. 2021, 57, 89-92. [CrossRef]

9. Casalinuovo, F.; Musarella, R. Isolation of Moellerella wisconsensis from the Lung of a Goat. Vet. Microbiol. 2009, 138, 401-402. [CrossRef]

10. Sandfort, R.F.; Murray, W.; Janda, J.M. Moellerella wisconsensis Isolated from the Oral Cavity of a Wild Raccoon (Procyon lotor). Vector Borne Zoonotic Dis. 2002, 2, 197-199. [CrossRef]

11. Wiktorczyk-Kapischke, N.; Skowron, K.; Kwiecińska-Piróg, J.; Białucha, A.; Wałecka-Zacharska, E.; Grudlewska-Buda, K.; Kraszewska, Z.; Gospodarek-Komkowska, E. Flies as a Potential Vector of Selected Alert Pathogens in a Hospital Environment. Int. J. Environ. Health Res. 2021, 1-20. [CrossRef] [PubMed]

12. Chilton, N.B.; Dergousoff, S.J.; Brzezowska, V.; Trost, C.N.; Dunlop, D.R. American Dog Ticks (Dermacentor variabilis) as Biological Indicators of an Association between the Enteric Bacterium Moellerella wisconsensis and Striped Skunks (Mephitis mephitis) in Southwestern Manitoba, Canada. J. Wildl. Dis. 2020, 56, 918-921. [CrossRef] [PubMed]

13. Stock, I.; Falsen, E.; Wiedemann, B. Moellerella wisconsensis: Identification, Natural Antibiotic Susceptibility and Its Dependency on the Medium Applied. Diagn. Microbiol. Infect. Dis. 2003, 45, 1-11. [CrossRef]

14. Centers for Disease Control and Prevention. Antibiotic Resistance Threats in the United States, 2019; US Department of Health and Human Services, Centres for Disease Control and Prevention: Atlanta, GA, USA, 2019. [CrossRef]

15. Guenther, S.; Ewers, C.; Wieler, L.H. Extended-Spectrum Beta-Lactamases Producing E. coli in Wildlife, yet Another Form of Environmental Pollution? Front. Microbiol. 2011, 2, 246. [CrossRef] [PubMed]

16. Veldman, K.; van Tulden, P.; Kant, A.; Testerink, J.; Mevius, D. Characteristics of Cefotaxime-Resistant Escherichia Coli from Wild Birds in The Netherlands. Appl. Environ. Microbiol. 2013, 79, 7556-7561. [CrossRef] [PubMed]

17. Jamborova, I.; Dolejska, M.; Zurek, L.; Townsend, A.K.; Clark, A.B.; Ellis, J.C.; Papousek, I.; Cizek, A.; Literak, I. Plasmid-Mediated Resistance to Cephalosporins and Quinolones in Escherichia Coli from American Crows in the USA. Environ. Microbiol. 2017, 19, 2025-2036. [CrossRef] [PubMed]

18. Bonnedahl, J.; Järhult, J.D. Antibiotic Resistance in Wild Birds. Upsala J. Med. Sci. 2014, 119, 113-116. [CrossRef] [PubMed] 
19. Athanasakopoulou, Z.; Reinicke, M.; Diezel, C.; Sofia, M.; Chatzopoulos, D.C.; Braun, S.D.; Reissig, A.; Spyrou, V.; Monecke, S.; Ehricht, R.; et al. Antimicrobial Resistance Genes in ESBL-Producing Escherichia Coli Isolates from Animals in Greece. Antibiotics 2021, 10, 389. [CrossRef]

20. Skrodenyte-Arbaciauskiene, V.; Sruoga, A.; Butkauskas, D. Assessment of Microbial Diversity in the River Trout Salmo trutta fario L. Intestinal Tract Identified by Partial 16S RRNA Gene Sequence Analysis. Fish. Sci. 2006, 72, 597-602. [CrossRef]

21. Saitou, N.; Nei, M. The Neighbor-Joining Method: A New Method for Reconstructing Phylogenetic Trees. Mol. Biol. Evol. 1987, 4, 406-425. [CrossRef]

22. Kimura, M. A Simple Method for Estimating Evolutionary Rates of Base Substitutions through Comparative Studies of Nucleotide Sequences. J. Mol. Evol. 1980, 16, 111-120. [CrossRef]

23. Felsenstein, J. Confidence Limits on Phylogenies: An Approach Using the Bootstrap. Evolution 1985, 39, 783-791. [CrossRef] [PubMed]

24. Tamura, K.; Stecher, G.; Kumar, S. MEGA11: Molecular Evolutionary Genetics Analysis Version 11. Mol. Biol. Evol. 2021, 38, 3022-3027. [CrossRef] [PubMed]

25. Giske, C.G.; Martinez-Martinez, L.; Cantón Spain, R.; Stefani, S.; Skov, R.; Glupczynski, Y.; Nordmann, P.; Wootton, M.; Miriagou, V.; Skov Simonsen, G.; et al. EUCAST Guidelines for Detection of Resistance Mechanisms and Specific Resistances of Clinical and/or Epidemiological Importance; EUCAST: Basel, Switzerland, 2017.

26. Dandachi, I.; Salem Sokhn, E.; Najem, E.; Azar, E.; Daoud, Z. Carriage of Beta-Lactamase-Producing Enterobacteriaceae among Nursing Home Residents in North Lebanon. Int. J. Infect. Dis. 2016, 45, 24-31. [CrossRef] [PubMed]

27. Bangert, R.L.; Ward, A.C.S.; Stauber, E.H.; Cho, B.R.; Widders, P.R. A Survey of the Aerobic Bacteria in the Feces of Captive Raptors. Avian Dis. 1988, 32, 53. [CrossRef]

28. Foti, M.; Siclari, A.; Mascetti, A.; Fisichella, V. Study of the Spread of Antimicrobial-Resistant Enterobacteriaceae from Wild Mammals in the National Park of Aspromonte (Calabria, Italy). Environ. Toxicol. Pharmacol. 2018, 63, 69-73. [CrossRef]

29. Magiorakos, A.-P.; Srinivasan, A.; Carey, R.B.; Carmeli, Y.; Falagas, M.E.; Giske, C.G.; Harbarth, S.; Hindler, J.F.; Kahlmeter, G.; Olsson-Liljequist, B.; et al. Multidrug-Resistant, Extensively Drug-Resistant and Pandrug-Resistant Bacteria: An International Expert Proposal for Interim Standard Definitions for Acquired Resistance. Clin. Microbiol. Infect. 2012, 18, 268-281. [CrossRef]

30. Madec, J.Y.; Haenni, M.; Nordmann, P.; Poirel, L. Extended-Spectrum $\beta$-Lactamase/AmpC-and Carbapenemase-Producing Enterobacteriaceae in Animals: A Threat for Humans? Clin. Microbiol. Infect. 2017, 23, 826-833. [CrossRef]

31. Palmeira, J.D.; Cunha, M.V.; Carvalho, J.; Ferreira, H.; Fonseca, C.; Torres, R.T. Emergence and Spread of Cephalosporinases in Wildlife: A Review. Animals 2021, 11, 1765. [CrossRef]

32. Wang, J.; Ma, Z.B.; Zeng, Z.L.; Yang, X.W.; Huang, Y.; Liu, J.H. The Role of Wildlife (Wild Birds) in the Global Transmission of Antimicrobial Resistance Genes. Zool. Res. 2017, 38, 55-80. [CrossRef]

33. Tufa, T.B.; Fuchs, A.; Wienemann, T.; Eggers, Y.; Abdissa, S.; Schneider, M.; Jensen, B.-E.O.; Bode, J.G.; Pfeffer, K.; Häussinger, D.; et al. Carriage of ESBL-Producing Gram-Negative Bacteria by Flies Captured in a Hospital and Its Suburban Surroundings in Ethiopia. Antimicrob. Resist. Infect. Control 2020, 9, 175. [CrossRef] [PubMed]

34. Mathers, A.J.; Peirano, G.; Pitout, J.D.D. The Role of Epidemic Resistance Plasmids and International High-Risk Clones in the Spread of Multidrug-Resistant Enterobacteriaceae. Clin. Microbiol. Rev. 2015, 28, 565-591. [CrossRef] [PubMed]

35. Ruppé, É.; Woerther, P.-L.; Barbier, F. Mechanisms of Antimicrobial Resistance in Gram-Negative Bacilli. Ann. Intensive Care 2015, 5, 21. [CrossRef] [PubMed]

36. Schaufler, K.; Semmler, T.; Wieler, L.H.; Wöhrmann, M.; Baddam, R.; Ahmed, N.; Müller, K.; Kola, A.; Fruth, A.; Ewers, C.; et al. Clonal Spread and Interspecies Transmission of Clinically Relevant ESBL-Producing Escherichia Coli of ST410-Another Successful Pandemic Clone? FEMS Microbiol. Ecol. 2016, 92, fiv155. [CrossRef]

37. Kagalou, I.; Tsimarakis, G.; Bezirtzoglou, E. Inter-Relationships between Bacteriological and Chemical Variations in Lake Pamvotis-Greece. Microb. Ecol. Health Dis. 2002, 14, 37-41. [CrossRef] 